\title{
Economic Growth And Sustainable Development: Sustainability or Sustainable Development?
}

\author{
William Deng Deng
}

\section{Précis}

Depuis les trois dernières décades, le débat surle développement durables'est caractérisé par une étroite politique de développement et de l'environnement laissant une large marge aux interprétations. Ces interprétations ne correspondent pas souvent à celles de ceux qui utilisent les forces $d u$ marché ainsi que les multinationales pour mieux actualiser le développement. Elles sont plutôt issues des théories qui croient en une réconceptualisation fondamentale de l'économie et de l'environnement pour qu'un réel changement se produise. Dans une approche théorique, cet article tente d'analyser la croissance économique et la complexité de la notion du développement durable.

\section{Introduction}

The need for a wider vision in the formulation of trade, environment and development policies-based on a clearer understanding of how these three factors are interrelated-has increasingly been recognized, and today's environmental concerns have potential for affecting development policies and global trade flows. Trade itself can have powerful effects on the environment and development.

The goal of this paper is to define the concept of "sustainable development." It is argued that sustainable development in the Third World cannot be carried out within the context of the present international economic order because of its inherent weaknesses on environmental policy.

The first part of this paper addresses the definition of "sustainable development" in conjunction with ecology. The second part concerns with its im-

William Deng Deng, a graduate researcher at CRS, is completing his Master's program in Environmental Studies, York University. plication on the developmental process in the developing countries. It is concluded that the present international economic order cannot promote sustainable development because environmental issues are not part of its agenda. This means that Third World governments will not be able to bring environmental policies to bear on the multinational corporations within their territories.

\section{The Concept of Sustainable Development}

The concept of "sustainable development" has deep roots in twentieth century theories of renewable resource management. This was later advanced as a more fully integrated approach to conservation and development in what became known as the World Conservation Strategy (IUCN 1980). Sustainable development has only recently been popularized by Our Common Future, the 1987 report of the World Commission on the Environment and Development, also known as the Brundtland Commission.

The Brundtland Commission defined sustainable development as "development that meets the needs of the present without compromising the ability of future generations to meet their own needs" (WCED 1987, 43). This innocuous skeletal definition gave something to everyone, including academics, governments, and nongovernment organizations, which have been striving ever since to flesh it out. As global ecological trends worsen, any concept that implies we can "eat our developmental cake and have our environment too" naturally inspires enthusiasm on all sides of the debate.

General concurrence on the need for sustainable development obscures equally widespread disagreement over the practical meaning of the con- cept. Environmentalists of all stripes and groups on the political left emphasize the "sustainable" part. They see a need to put the Earth first, limit material growth, return to community values and devise ways to share the world's wealth more equitably. Economic planners, the political centre and all those to the right, lean more to the "development" component. From their perspective, there are no limits, growth comes first, the capitalist system works, and the global expansion of market economies will create the wealth needed for world ecological and social security.

While proponents of sustainable development occupy the entire political spectrum, the debate is becoming polarized around two distinctive features, each with its own normative assumptions and distinctive vision of humankind's role in the scheme of things. For example, Milbrath (1989) refers to the two as the "dominant social paradigm" and "environmental paradigm." Taylor (1991) calls them the "expansionist worldview" and the "ecological worldview."

The Brundtland Commission was curiously ambiguous in elaborating its definition of sustainable development. Our Common Future defines "needs" as the "essential needs of the world's poor, to which over-riding priority should be given." It also acknowledges the "limitations imposed by the state of technology and social organization on the environment's ability to meet those needs" (WCED 1987, 43). To those concerned about ecology and social equity, such words seemed to be a plea for political recognition of global economic injustice and limits to material growth.

But there is another side to Our Common Future that guaranteed its message would be as enthusiastically 
received in corporate boardrooms around the world. The report reassuringly asserts that "sustainable development is not a fixed state of harmony, but rather a process of change in which the exploitation of resources, the orientation of technological development, and institutional change are made consistent with future as well as present needs" (WCED 1987, 9). Achieving sustainable development is said to depend on broader participation in decision-making; new forms of multilateral cooperation; the extension and sharing of new technologies; international investment; an expanded role for transnational corporations; the removal of "artificial" barriers to commerce; and expanded global trade.

In effect, the Brundtland Commission equated sustainable development with "more rapid economic growth in both industrial and developing countries" on the grounds that "economic growth and diversification will help developing countries mitigate the strains on the rural environment" (WCED 1987, 89). Consistent with this interpretation, the Commission observed that "a five to tenfold increase in world industrial output can be anticipated by the time world population stabilizes some time in the next century" (WCED 1987, 213). ${ }^{1}$ In recognition of the additional stress this implies for the environment, the Commission cast sustainable development in terms of more material and energy efficient resource use, new ecologically benign technologies, and "a production system that respects the obligation to preserve the ecological base for development" (WCED1987,65). However, there is no analysis of whether the anticipated growth would be biophysically sustainable under any conceivable production system.

Government response to the Brundtland Commission in the industrial democracies is summed up by the Canadian "National Task Force on Environment and Economy" (CCREM 1987). In taking its cue from the Brundtland Commission, the task force defined sustainable development as "development which ensures that the utilization of resources and the environment today does not damage prospects for their use by future generations." Ignoring the obvious difficulty posed by the consumption of non-renewable resources in any generation, the report goes on to suggest that "[a]t the core of the concept ... is the requirement that current practices should not diminish the possibility of maintaining or improving living standards in future." Perhaps most revealing is the assertion that:

[s] ustainable economic development does not require the preservation of the current stock of natural resources or any particular mix of human, physical and natural assets. Nor does it put artificial limits on economic growth provided such is both economically and environmentally sustainable. (CCREM 1987, 3)

Certainly no one can accuse this task force of confusing sustainable development with any "fixed state of harmony." Both the Brundtland Commission and the Canadian Task Force reflect the prevailing interpretation of sustainable development in the political mainstream and on the right in the industrialized countries. Governments and industry increasingly acknowledge that present development practices do produce significant environmental and socioeconomic stress. However, without examining the systemic roots of either poverty or ecological decay, both reports assert that the solutions to these crises reside within the same socioeconomic structures from which they have sprung.

Even the protagonists of Our Common Future who recognize its radical implications acknowledge that its authors "have turned out to be their own enemies, they failed to draw out the implications of their own statements" (Brooks 1990, 24). More virulent critics argue that its analysis is superficial or lacking. Because it fails to identify and analyze the causes of global poverty and ecological decline, it advances solutions that are the direct opposite of those required. By not challenging the assumptions driving an increasingly market-driven global economy; by ig- noring the connection between global ecological concerns and profligate lifestyles of industrialized countries; by putting their faith in the "in-discriminate growth and trickle down approach to Third World development;" the Commissioners produced a thoroughly conventional statement. The Brundtland Report "constitutes an enthusiastic and unquestioning re-affirmation of the system, life-styles, and values that are causing the problems under discussion" (Trainer 1990, 72).

Most important, Our Common Future advances economic growth as the principal vehicle for sustainability in the apparent trickle-down belief that eventually the poor will benefit and sufficient economic surpluses will be available for ecosystem maintenance. Tenuous assumptions aside, many analysts find this continuing reliance on growth to be the most troubling aspect of the mainstream prescription for: sustainable development. The World Commission "reveals no acquaintance with any of the executive literature now supporting \{challenges\} to the growth conception of development" (Trainer 1990, 79). Indeed, the Commission's work was little influenced by science of any kind, its mandate ensured that the Commission "was most concerned with values" (Timberlake 1989, 117). As a result, for all its pervasive influence, Our Common Future is a political document, not a scientific one. "The claim that we can have economic growth without damaging the environment is a sheer statement of opinion" (Timberlake 1989, 122).

Maybe the fixation on growth per se should not come as surprise. Our "largely uncritical worship of ... economic growth is as central to (capitalism's) nature as the similar veneration of ... divine kingship or doctrinal orthadoxy has been for other regimes" (Heilbroner 1989, 102).

Nevertheless, given the "sustainability" theme, it is remarkable that neither the Brundtland Commission nor the Canadian Task Force distinguishes between growth which "should refer to quantitative expan- 
sion in the scale ... of the economic system," and development which "should refer to the qualitative change in a physically non-growing economic system in dynamic equilibrium with the environment" (Daly and Cobb $1989,71)$. By these definitions, sustainable growth in a finite environment is a logical impossibility but sustainable development contains no self-contradiction. This simple distinction between mere growth and true development is essential to rational debate on developing sustainability, but has scarcely entered the discussion.

There is a historical basis for this reticence. Economic growth has long been the principal instrument of social policy in capitalist societies. "If we can have perpetual growth, those who are relatively well off won't have to share their wealth with others" (Miernyk $1982,4)$. Thus, "we refuse to fight poverty by redistribution and sharing, ... leaving 'economic' growth as the only acceptable cure" (Daly 1990, 118). The promise of an ever-increasing economic pie holds out hope that even the poor will eventually get an adequate share. This expectation reduces popular pressure for policies aimed at more equitable distribution of national incomes.

While morally bankrupt, this "solution" to social inequity posed no physical threat to society as long as the economy was small relative to the scale of the ecosphere. This is no longer the case, and in advancing growth as a solution once again, mainstream authors make no attempt to weigh the anticipated future scale of the global economy against the finite productive capacity of the ecosphere.

In fairness, it should be noted that conventional economic analysis cannot even pose the proper question. "Macro-economic theory has nothing to say about the appropriate scale of the economic" (Daly 1989, 1990). The idea of continuous growth is so firmly entrenched that the issue of scale has apparently not been considered relevant. By contrast, from the ecological perspective, it is very much an open question whether it is possible to ex- pand industrial production by a factor of five to tenfold while simultaneously guaranteeing "the sustainability of ecosystems upon which the global economy depends" (WCED 1987, 67).

\section{Ecological Deterioration}

Sustainable development, as a goal, rejects policies and practices that support corrupt living standards by depleting the productive base, including natural resources, and which leave future generations with poorer prospects and greater risks than our own. (Repetto 1986, 15)

There can be little doubt that present reactive responses to global ecological deterioration compromise our own potential and "shift the burden of environmental risks to future generations" (Pearce et al. 1989, 19). Any proactive prescription for sustainable development must acknowledge the primary role of bio-resources in human survival and the inequity inherent in current practice. Maintenance of the functional integrity of the ecosphere is a necessary prerequisite to extending the time horizon for economic policy and to elevating intragenerational equity to a place of prominence in developmental decision-making.

This reasoning would suggest that as an ecological bottom line for sustainable development, humankind must learn to live on the "interest" generated by the remaining stocks of living "natural capital." Any human activity dependent on the consumptive use of ecological resources cannot be sustained indefinitely because it not only consumes annual production, but also cuts into capital stocks (Rees 1990).

The recognition that bio-resources must be treated as unique forms of productive capital is the major contribution of the emerging hybrid discipline of "ecological economics" (Costanza 1991). Its implications for development are currently being explored through various interpretations of a "constant capital stocks" criterion for sustainability (Costanza 1991; Daly 1990, 1989; Pearce and Turner 1990; Pearce et al. 1989, 1990).
In essence, adherence to this criterion would require that each generation leave the next generation an undiminished stock of productive assets. There are two possible interpretations of the constant capital stock idea (adapted from Pearce et al. 1989). Both of them assume that existing stocks are adequate. If populations are growing or material standards increasing, the stock of productive capital would have to be increased to satisfy the demand. The first is that each generation should inherit an aggregate stock of manufactured and natural assets, no less than the stock inherited by the previous generations. This corresponds to Daly's (1989) conditions for "weak sustainability." The second interpretation is that each generation should inherit only a stock of natural assets, which are no less than the stock of such assets inherited by the previous generation. This corresponds to a version of "strong sustainability" as defined by Daly (1989). The second interpretation better reflects the ecological principles advanced above. In particular, maintaining natural capital stocks recognizes the multi-functionality of biological resources everywhere, "including their role as life support systems" (Pearce et al. 1990, 7). In this respect, "strong sustainability" recognizes that manufactured and natural capital "are really not substitutes but complements in most production functions" (Daly 1989, 22).

Agriculture provides "a context in which life (can) function in a meaningful manner" (Berry 1988, 123) and profoundly affects how its members act in the world. The internal contradictions of our prevailing economic story can be traced to the 19th century founders of the neoclassical school. Impressed with the successes of Newtonian physics, they set about to create economics as a sister science, "the mechanics of utility and self-interest" (Jevons 1879, cited in Gergescu-Roegen 1975). The shift to a mechanical rather than biological metaphor for the economy was a critical one. While economics is (or should be) a branch of human ecology, the central assumptions of modern 
economic theory are uninformed by ecological principles. The resultant theory produces analytical models based on reductionist and deterministic assumptions about resources, people, firms and technology that bear little relationship to their counterparts in the real world (Christensen 1991). Three closely related assumptions of the mechanical model are sufficient to illustrate this historic divergence. First, industrial society perceives the human enterprise as dominant over and essentially independent of nature. This economy-environment separation is actually a social construct reflecting the Cartesian subject-object dualism at the heart of western scientific materialism. Accordingly, the very word "environment" becomes its own pejorative, diffidently declaring itself to be peripheral, unimportant, and not to be taken seriously (Rowe 1989).

Consistent with this perspective, prevailing economic theory lacks any material specification of energy and material inputs to economic production and ignores completely the backward linkages of resources to ecosystem structure or function. The economy may use "the environment" as a source of resources and as a sink for wastes (Herfindahl and Kneese 1974), but beyond that, it is treated as a mere static backdrop to human affairs.

Secondly, economists have adopted the circular flow of exchange values as the starting point for analysis rather than the entropy characterizing energy and matter (Daly 1989,1). The major consequence is an entrenched view of economic process as "a self-sustaining circular flow between production and consumption" By this perception, "everything ... turns out to be just a pendulum movement ... If events alter the supply and demand propensities, the economic world returns to its previous position as soon as these events fade out." Most importantly, "[c]omplete reversibility is the general rule, just as in mechanics" (GeorgescuRoegen 1975, 348). Indeed, by inventing a perpetual motion machine, economics seems to have done mechanics one better.

Thirdly, we have come to believe that resources are more the product of human ingenuity than they are of nature (Hall 1990). According to neoclassical theory, rising market prices for scarce materials encourage conservation on the one hand and stimulate technological substitution on the other. It has become part of the conventional wisdom of many economists and planners that technological progress and substitution are more than sufficient to overcome emerging resource scarcities (Victor 1991, 200).

While standard neoclassical texts conclude almost conservatively that "exhaustible resources do not pose a fundamental problem" (Dasgupta and Heal, 1979:205), the most ardent disciples of the sustainability principle are moved to near-extremes. Gilder argues that we "must overcome the materialistic fantasy; the illusion that resources ... are essentially things, which can run out, rather than products of human will and imagination in which freedoms are inexhaustible" (Gilder 1981, 232, cited in Daly and Cobb 1989, 109). Similarly, Simon $(1982,207)$ remarks: "You see, in the end copper and oil come out of our minds. That is really where they are." So pervasive is this doctrine that they use it to argue for further population growth on the grounds that people "create the wealth they need to maintain themselves and more, thanks to free markets and technological progress" (Block 1991, 304).

Economic theory necessarily contains a model of nature. The key assumptions of the contemporary model range from mechanical dualism on one extreme to metaphysical idealism on the other. Together they describe an economic system which, being functionally independent of physical reality has unlimited potential to expand. Add open access to resource systems (the so-called "common property" problem) and future discounting (particularly in the face of uncertainty) and we have a system in which there are often "no economic forces whatever acting in favour of sustainable development" (Clark 1991).

Determining what mix and just how much of the ecosystems capital to preserve remains a major problem. Neoclassical theory suggests that "development" should proceed only to the point at which the marginal costs of natural capital depletion (diminished ecological services) begin to exceed the marginal benefits produced (additional jobs and income). However, this assumes that we can identify, quantify and price all relevant life support functions and that any change in the properties of ecosystems under stress will be smoothly continuous (i.e., predictable) and reversible. Unfortunately, neither assumption holds.

On the contrary, the reliability of the ecosphere's life support function positively correlates with high levels of species diversity and structural complexity. Maintaining biological diversity is therefore a primary goal of natural capital conservation. Diverse natural systems and dependent economic systems display greater resilience (resistance to shock or stress) than species-improvised managed systems such as agricultural monocultures. More important still, robust ecosystems are essential for autopoiesis. Sustainable development is impossible in a thermodynamically far-from equilibrium world unless the ecosystems upon which humans depend are capable of continuous selforganization and production.

However, they also note that further reductions of natural capital may impose significant risks on society, "even in countries where it might appear we can afford to (reduce stocks)." These risks reside in our imperfect knowledge of ecological functions, in the fact that loss of such functions may be irreversible and in our inability to substitute for those functions once lost. In short, because of the unique essential services provided by ecological capital, "conserving what there is could be a sound risk averse strategy" (Pearce et al. 1990, 7).

Ironically, these conclusions, based on a modification and extension of the

Refuge, Vol. 15, No. 2 (April 1996) 
mainstream neoclassical paradigm, actually provide greater support to the once radical ecological world-view. Are we now ready to begin seriously to contemplate the adjustments necessary to industrial economies like those of the US and Canada. Should we come to accept that a tolerable future requires diversion of much current consumption to maintenance or rehabilitation of the planet's declining natural assets?

\section{Links between Poverty and Environmental Degradation in the Third World}

The relationship between poverty and the environment on a different continent, and in the Third World in particular, is an inter-linkage that is important for the understanding of environmental issues. This is because poverty and the environment are linked in a close and complex way.

There is a need to understand the impact of colonialism on the natural environment in order to appreciate the causes of this environmental crisis in the Third World. In a wider geographical context, the creation of degraded environments cannot be seen as simply an unfortunate by-product of the development process. It is an inherent part of that process itself and the way in which development projects are planned and executed. In this context, environmental degradation is associated with economic growth, industrial pollution, pesticides and the physical and ecological impacts of water control. In that respect, there was a total disregard of the ecosystems.

Our understanding of ecosystems is still uncertain. They are characterized by thresholds, critical points beyond which all relationships change dramatically, triggered by events such as the extinction of a critical species in a food chain or an overloading of pollutants beyond the point of assimilative capacity. They are often unforgiving of errors in modelling and forecast. Many times, the resulting environmental change cannot be easily reversed, if at all. Conserving irreversible natural resources is the most important pro- gramme for the Third World. Pearce et al. (1990), observed that conserving natural capital may seem particularly relevant to developing countries in which socioeconomic stability is immediately and directly threatened by deforestation, desertification, soil erosion, falling water tables, etc. In these circumstances there can be little doubt that existing stocks of natural capital are well below bio-economic optima and must actually be enhanced for survival let alone sustainability.

Equity is another factor which the Third World should always put into consideration. Equity relates to the distribution both within and between generations of physical and natural capital, as well as knowledge and technology. In the transition to sustainability, additional obligations should be assumed by those, primarily in the developed World, who have used resources in the past in a manner which limits the options of present generations, particularly in developing countries. Trade liberalization can contribute to greater equity through the dismantling of trade barriers that harm developing countries.

While domestic equity is a fundamental goal of some governments, policies to achieve it are hard to implement. In seeking to promote greater equity it is impossible to strive for growth to generate additional resources for distribution, or to seek better distribution of existing resources, but the two are not mutually exclusive.

Inequity and poverty contribute significantly to environmental degradation and political instability, particularly in the Third World. When basic needs are not met, the poor have no choice but to live off whatever environmental resources are available. At the same time, past use of natural resources already limits the choices available to present generations, particularly in developing countries. Faced with these limitations and having limited financial, administrative and technical capacity to deal with problems of environment and development, many Third World countries will require enormous transfers of technology and financial resources. Failing such assistance, they may be unable to adequately protect their environmental resources, including many which are of global significance.

The substantial investment needed for sustainable development requires new and additional external resources in Third World countries far in excess of conceivable increases in traditional foreign aid programmes. Increased trade and investment flows, the result of more open borders in both developed and developing countries, together with appropriate domestic policies in developing countries, are the best alternative for increasing incomes in poorer countries by the magnitudes necessary to achieve sustainable development. Other measures to achieve equity and poverty alleviation include strengthening the capacity of developing countries to develop indigenous technologies and to manage environmental resources, and creating mechanisms for the accelerated transfer of existing technologies. Continued progress in resolving the debt crisis is also important, as is an increase in transfers of financial resources. At the same time, developing countries must adopt policies which ensure that the additional resources are used in ways that are efficient, alleviate poverty and foster sustainable practices.

\section{Conclusion}

Central to the sustainable development debate are the twin policies of development and caring for the environment concurrently. The concept is a controversial subject.

At the international level, it should be realized that the present crisis is being generated by the unsustainable economic model in the North, inappropriate development patterns in the South, and an inequitable global economic system that links the Northern and Southern models. There must be a change of development patterns in the South-towards models that are environmentally sound, make use of appropriate technology, and satisfy basic needs of all. 
But it is even more important and difficult to alter the parent economic model in the North, where 20 percent of the world population consumes 80 percent of world resources. Changes in the world economic order are necessary as mechanisms to bring about greater equity in the Third World. These include better terms of trade for the developing countries. For instance, if the volume of natural raw material production is to be reduced (to slow resource depletion), the North should pay at prices comparable to home market rates for Third World commodities in order to avoid the poor having to bear the costs of adjustment. There must be a democratisation of the Bretton Woods institutions (World Bank, IMF, GATT) and a change in their operational principles from narrow commercial interests to human and sustainable development. The transnational corporations have to be made more accountable through international monitoring and regulatory mechanisms.

Many of environmentally and socially appropriate technologies exist in the South, in the areas of agriculture, water retention and harvesting, industry energy, shelter, medicine and health care, food preparation and nutrition. These technologies and practices continue to be destroyed by "modernization" and commercialisation. They should be recognized, rediscovered, restored and regenerated as part of the process of sustainable development. It is a fallacy to think that all environmentally sound technologies must originate in commercial sectors of the North. If we care about the future generations and the future of the planet, sustainable development is the only way out.

\section{Notes}

1. This may seem like an extraordinary rate of economic expansion, but it implies an average annual growth rate in the vicinity of only 3.5-4.5 percent over the next fifty years. Growth of this kind has already produced a near fivefold increase in world economic output since the Second World War.

\section{Bibliography}

Berry, T. 1988. The Dream of the Earth. San Francisco: Sierra Club Books.

Block, W. 1991. Environmental Problems, Private Property Rights Solutions. In Economics and the Environment: $A$ Reconciliation, edited by $W$. Block. Vancouver: The Fraser Institute.

Brooks, D. 1990. "Beyond Catch Phrases: What does Sustainable Development Really Mean?" IDRC Reports, October.

Capra, F. 1982. The Turning Point. Toronto and New York: Bantam Books.

CCREM. 1987. Report of the National Task Force on Environment and Economy._Ottawa: Canadian Council of Resource and Environment Ministers.

Christensen, P. 1991. “Driving Forces, Increasing Returns and Ecological Sustainability." In Ecological Economics: The Science and Management of Sustainability, edited by R. Costanza. New York: Columbia University Press.

Clark, C. 1991. Economic Biases Against Sustainable Development. In Ecological Economics: The Science and Management of Sustainability, edited by R. Costanza. New York: Columbia University Press.

Costanza, R. 1990. "Natural Capital and Sustainable Development." Paper prepared for the CEARC Workshop on Natural Capital, Vancouver, BC, March 1990, 1516. Ottawa: Canadian Environmental Assessment Research Council.

Daly, H. 1990. “From Empty World Economics to Full World Economics: Recognizing an Historic Turning Point in Economic Development." In Environmentally Sustainable Development: Building on Brundtland (May 8, 1991 draft), edited by R. Goodland, H. Daly, and S. El Serafy. Washington, DC: The World Bank.

Daly, H., and J. Cobb. 1989. For the Common Good: Redirecting the Economy Toward Community the Environment, and a Sustainable Future. Boston: Beacon Press.

Daly, H. 1989. "Sustainable Development: From Concept and Theory Towards Operational Principles." Presented to Hoover Institute Conference. (Manuscript prepared for special issue of Population and Development Review.) Also included in H. Daly, 1991, Steady-State Economics (2nd ed.) Washington: Island Press.

Dasgupta, P., and D. Heal. 1979. Economic Theory and Exhaustible Resources. London: Cambridge University Press.

Georgescu-Roegen, N. 1975. "Energy and Economic Myths." Southern Economic Journal, 41:3:347-81.
Gilder, G. 1981. Wealth and Poverty. New York: Basic Books.

Hall, C. 1990. "Sanctioning Resource Depletion: Economic Development and NeoClassical Economics." The Ecologist, 20:3:99-104.

Heilbroner, R. 1989. "The Triumph of Capitalism." The New Yorker, January 23.

Herfindahl, O., and A. Kneese. 1974. Economic Theory of Natural Resources. Columbus, Ohio: Charles E. Merill.

IUCN. 1980. World Conservation Strategy. Gland, Switzerland: International Union for the Conservation of Nature.

Miernyk,W.1982. The Illusions of Conventional Economics. Morgantown: West Virginia University Press.

Milbrath, J. 1989. Envisioning a Sustainable Society: Learning Our Way out. Albany, NY: Albany State University Press.

Nelson, J. 1990. "An Attempted Corporate Takeover." Deconstructing Ecology.

Nikiforuk, A. 1990. "Sustainable Rhetoric." Harrowsmith, October.

Pearce, D. et al.1989. Sustainable Development, Economics and Environment in the Third World. Hants, England: Edward Elgar Publishing.

Rees, W. 1990. "Sustainable Development and the Biosphere: Concepts and Principles." Teilhard Studies 23. American Teilhard Association.

Repetto, R. 1986. World Enough and Time. New Haven, Conn.: Yale University Press.

Rowe, S. 1989. "Implications of the Brundtland Commission Report for Canadian Forest Management." The Forestry Chronicle, February, 5-7.

Simon, J. 1982. "Interview with William F. Buckley, Jr." Population and Development Review, March, 205-18.

Taylor, D. 1991. “Sustaining Development or Developing Sustainability? Two Competing World-Views." Alternatives.

Timberlake, L. 1989. "The Role of Scientific Knowledge in Drawing up the Brundtland Report." In International Resource Management: The Role of Science and Politics, edited by S. Andresen and W. Ostreng, 118-23. London: Belhaven Press.

Trainer, T. A. 1990. Rejection of the Brundtland Report. New York: International Foundation for Development Alternatives(IFDA DOSSIER).

Victor, P. A. 1991. "Indicators of Sustainable Development: Some Lessons from Capital Theory." Ecological Economic.

WCED, Brundtland Commission. 1987. Our Common Future. Oxford: Oxford University Press. $\square$ 